\title{
The Ethical and Spiritual Project of Martin Prozesky: Influences and Interests
}

\author{
Maniraj Sukdaven \\ maniraj.sukdaven@up.ac.za
}

\begin{abstract}
This article provides a cursory overview of the life and thought of Professor Martin Prozesky, and his contributions to academia via his ethical and spiritual project. There were many people of various personalities that influenced his life, including the path he chose in academia. Some of these were scholars, such as the internationally acclaimed Professors Alister Hardy, John Hick, Lloyd Geering, Ninian Smart, Wilfred Cantwell Smith, feminist Professors Mary Daly, Ursula King and Rosemary Radford Ruether, and various process theologians. Others were spiritual leaders such as Archbishop Desmond Tutu, Mahatma Gandhi, the Chief Rabbi of the orthodox United Hebrew Congregations of the Commonwealth (1991 - 2013), Jonathan Sacks, and the Dalai Lama.
\end{abstract}

From his base in Theology and Religious Studies to his move to Ethics and Spirituality it could be established that there are five main contributions in Martin Prozesky's work which he had made to academia and of which cognizance should be taken. These are: (1) the religious philosophy of Friedrich Schleiermacher; (2) the development of a critical theology; (3) his values-based explanation of religion; (4) the debate about God; and (5) the need for a multi-cultural, even global, multi-disciplinary approach to applied ethics with special attention to African ethics. These contributions among other works are discussed in this article. (The article was made possible through an interview with Prof. Prozesky that was recorded and transcribed.)

Keywords: religious philosophy, Friedrich Schleiermacher, critical theology, values-based explanation of religion, debate about God, multi-cultural approach, applied ethics, African Ethics 


\section{Introduction}

In this celebratory Festschrift article I present the life and thought of Professor Martin Prozesky, to discuss his contribution to academia. I interviewed him in October 2013 that was recorded and transcribed. The transcription is available on request. Where necessary in-text-referencing to books and/or articles were made to enhance aspects of the interview and to confirm references made by Prozesky to authors in the interview. Encapsulated in this article are his main contributions as an academic to both the ethical and the spiritual project. Cognizance is taken of various personalities and their influence in his life and the path he chose in academia.

\section{Martin Prozesky's Main Contributions as an Academic}

Martin Prozesky made five main contributions. These focus on religious philosophies, especially of Friedrich Schleiermacher amongst others, and the development of a critical theology, of which Schleiermacher in his valuesbased explanation of religion, the debate about God, and the need for a multicultural, even global, multi-disciplinary approach to applied ethics with special attention to African ethics, was influential. Before proceeding to these issues, it is illuminating to start with the sources of his outlook and interests in his home and boyhood, early church life and university experiences.

\section{Early Influences}

Although born in Newcastle on the 23 October 1944, Martin Prozesky's boyhood home and Anglican parish were in Oudtshoorn. This had a lasting impact on his life and thinking. His parents and the local clergy shared a deep, religious conviction that apartheid was a grave evil. This fostered in the young Martin a perception that the most valuable aspect of Christianity was its ability to resist major evils like racism and to foster a just and caring kind of society, a perception that was much encouraged by reading Trevor Huddleston's stinging denunciation of apartheid as unchristian in his book Naught for your Comfort (Huddleston 1956), and later by Chief Albert Luthuli's impassioned call for liberation from apartheid in Let my People Go (Luthuli 1962). Based on these experiences Prozesky decided to offer himself as a candidate for the Anglican priesthood while still at school. 
Developing a perception of the church as a powerful force for social justice in a town where most of the white, church-going people supported the apartheid government, was an important early exposure to a moral ambivalence in the churches that would figure strongly in Prozesky's later critique of Christianity and of traditional religion in general, as will be addressed later in this article.

A second youthful experience that also had a life-long effect came from friendships with Jewish classmates. Thus began a life- and beliefchanging contact with people from other faiths, whose own strong moral values and deep faith led Prozesky to a belief in universal salvation and then to a rejection, on ethical grounds, of all exclusivist religious teachings.

A third early factor in the shaping of Prozesky's work and outlook was his introduction to philosophy by a school teacher at the former Boys' High School in Oudtshoorn, the late Samuel Bosman. In Martin's penultimate year at school Bosman spoke to the class about René Descartes and his famous dictum of cogito ergo sum - 'I think, therefore I am'. Martin was captivated and began to see the power of reason in philosophy as an essential way of approaching religious and ethical questions. Later experiences of philosophy would encourage this early approach, especially in connection with Process Philosophy.

\section{University Studies}

Prozesky began his theological studies at Rhodes University in 1963 as a candidate for the Anglican priesthood and continued his studies at Trinity College, Oxford (1966-68) and at the Episcopal Theological School in Cambridge, Massachusetts (1968-69). It was at the latter, however, that he came to accept that the priesthood was not for him and that his future probably lay in the academic field. As he puts it, he had to face the reality that he was not a pastor but had a gift for teaching and public speaking. In the meantime, at Rhodes University, there was a lecturer who would strongly encourage Prozesky's belief that the heart of religion at its best was ethical and not doctrinal. He was Dr. Basil Moore who taught Systematic Theology and would later be a professor of Religion Studies at the University of South Australia in Adelaide.

Prozesky recalls Moore's impact as follows: 
What stood out in Basil's theology for me was his interpretation of salvation. He saw it not as something in an afterlife in heaven. Although he didn't deny that, what he did, was to emphasize very strongly the reality of salvation as something that needed to start happening now. He defined it as 'a community-creating event' based on love as pioneered by Christ. I still remember him emphasizing that if God is love and love is God, then love is divine. That was very powerful for me and others and coupled to it, Basil was outspokenly active in spreading a Christian anti-apartheid message. He bravely lived out the prophetic, ethical theology he taught (cf. Moore 1973).

\section{Schleiermacher Studies}

Prozesky's doctoral dissertation investigated the background and work of Friedrich Schleiermacher, with his well-known and pioneering appeal to religious experience (Prozesky 1976). Prozesky affirms that this was an important experience for him. He chose Schleiermacher for his doctorate because he had studied him in detail at Oxford and quickly found in him a very powerful, original thinker, and also an antidote to the Barthian theology he had encountered at Rhodes and elsewhere. Its longer term impact was to foreground religious experience in his own later work on the explanation of religion which led to his first book, Religion and Ultimate Well-Being: An Explanatory Theory (Prozesky 1984).

In his doctoral research Prozesky explored the seeming contradiction of a very revolutionary new approach to religion and Christianity from someone who had been schooled in pietism, which is well-known for its doctrinally conservative and inward-looking character. While his doctorate focused on the pietistic element in Schleiermacher's work, inevitably it also gave Prozesky a detailed knowledge of the place of religious experience in the life and thought of his doctoral subject, which, as was mentioned above, became part of his own approach to religion in his first book and ever since. Looking back to his work on Schleiermacher, Prozesky mentions that this radical young religious thinker impressed him, giving him and others like John Hick an experiential method of understanding religion that has proved exceptionally fertile (Prozesky 1981a; 1981b). 


\section{Scholars who also Influenced Prozesky's Work}

A number of leading, contemporary scholars played a much-valued part in Prozesky's unfolding approach to religion and ethics. In the order of his contact with them, either in person or through their writings (or both), they are Alister Hardy, John Hick, Lloyd Geering, Ninian Smart, Wilfred Cantwell Smith, several process thinkers, and the feminist scholars Rosemary Radford Ruether and Ursula King.

Alister Hardy. The work of Sir Alister Hardy (Hardy 1979), who had called in the 1970s for public contributions to his investigation of religious experiences and had built up an archive of about 5000 of these documents, added a fresh, empirical element to the focus on religious experience which became a permanent part of Prozesky's work. Off course Hardy (1979) did not use this data to support any religious doctrine or creed, but leant support for 'experiential faith'. In researching his first book Prozesky had access to a random sample of about 700 of these records. It showed repeatedly that if you want to understand religion look at first-hand evidence of religious experience (James 1902). Prozesky believes that this evidence shows that religion is fundamentally about finding the greatest of benefits, or blessings, to use religious terminology, understand by those concerned as some or other kind of deliverance, salvation or liberation.

John Hick. Encouraged by this emphasis on religious experience, Prozesky worked out the essentials of an understanding of the various religions which centralized the quest for the ultimate benefit of salvation, deliverance and liberation. It was at that time that his long and immensely valuable association with John Hick began. He met Hick when Hick was a visiting professor at the University of Natal in the early eighties. He already knew of Hick's work and continued to study all his later writings. Prozesky regarded it as a great privilege to have had personal contact and friendship with Hick until his death.

Prozesky identifies two ways in which Hick impacted him. First it was Hick's pioneering search for an answer to the question posed by the plurality of religions that culminated in his landmark book An Interpretation of Religion (Hick 1989; Prozesky 2012). Hick contended that there are no objective norms by which we can judge any of the world religions to be intellectually or morally superior to the others. All of them are effective paths to a transformation from 


\section{Maniraj Sukdaven}

self-centeredness towards what Hick sometimes called reality-centeredness. This impacted on Prozesky's own, ethics-based approach to religious pluralism.

The second impact was the invitation by Hick, while visiting Pietermaritzburg, for Prozesky to develop his view of religion into a book for the series Hick was editing for The Macmillan Press in Britain, called the Library of Philosophy and Religion. This led to Prozesky's first book as mentioned above.

Lloyd Geering. Sir Lloyd Geering, became a very good friend to Prozesky. Geering was present at the first international conference in1981 at which Prozesky spoke on the theme that there is morally bad religion and that South Africa offers a particularly disturbing example of it through the support of some of the biggest Christian churches for apartheid. According to Prozesky, Geering was very supportive of his presentation and they became friends.

Prozesky considers that the next great lesson he learnt from Geering was his ability to unfold an enormously sweeping view of the history of ethics and religion. He sees them as having developed through two great transitions (Geering 1980). Using Karl Jaspers' idea of an axial age of religion in the period just before and after about 500 BCE when many so-called world religions emerged, or in which they have foundations, Geering suggested a second such axis, or as he calls it, a second threshold or great turning point in the evolution of religion starting in about 1750 with developments like the rise of science and the enlightenment. Geering argued that this second great threshold is a movement towards the possibility of a secular, global period of faith and ethics (Geering 1991). According to Prozesky it was this way Geering encouraged him to seek the widest possible perspective on religion and ethics in his own work. Among other results was Prozesky's extension of his studies into the main secular philosophies; a development that is covered later in this article.

Geering's other main contribution to Prozesky's work concerns the critique of traditional Christianity and especially its traditional concept of God (Geering 1994; 2009). This began with his support for Prozesky's critique of traditional theistic religion at the international conference in 1981, already mentioned above, and continued down the years through the provision of supportive critical comments of Prozesky's own writings on this issue and others (Prozesky 1985a; 1985b). 
Ninian Smart. At John Hick's instigation Prozesky took his first sabbatical in Claremont, California where Ninian Smart was a professor at the University of California in Santa Barbara. Prozesky made contact with him personally and again when he came to South Africa for a visit to the University of Cape Town. Smart strongly supported the key phrase in Prozesky's first book, which he was researching in that sabbatical in Claremont in 1982, wherein he describes the various religions as quests for ultimate well-being in the form of their various teachings about achieving heaven, paradise and release or Nirvana as the greatest good that could ever come one's way. Prozesky proposed the term about quests for ultimate well-being in a conference at the beginning of that sabbatical in Claremont. Prozesky recalls that Ninian Smart was in the audience and he said that it was a good phrase to use.

Well before this event, Smart had provided an earlier benefit to Prozesky's work in comparative religion while he was lecturing at the former University of Rhodesia from 1971 to 1976. This was Smart's model (later modified slightly) of religion as having six dimensions: the experiential, the doctrinal, the ritual, the ethical, the social and the mythological, in a book called revealingly The Religious Experience of Mankind (Smart 1969; 1997). When Prozesky moved from religious studies to comparative ethics studies in 1997, he began to use this view in relation to the moral facet of human existence, presenting it in a so-far unpublished conference paper for the Association for the Study of Religion in Southern Africa (Prozesky 2011).

Wilfred Cantwell Smith. John Hick and Lloyd Geering were both responsible for introducing Prozesky to the work of Wilfred Cantwell Smith in the early 1980s. After reading his seminal books The Meaning and End of Religion and Faith and Belief (Smith 1978; 1979), Prozesky was able to meet Smith both at Harvard University, where he was the professor of world religions, and in New Zealand, at and after the 1983 international conference to mark Lloyd Geering's retirement. Before meeting Smith at Harvard University, Prozesky confirmed that he had sent him a paper he had written on Schleiermacher's first account of religion (Prozesky 1981a). Apparently Smith replied encouragingly. Thereafter it was really his work on the difference between faith and belief, which was also explained by Wainwright (1984:355), which Prozesky regards as the most important of the things he learnt from Smith, who regards faith as the core reality of religion, defining it as an orientation to transcendence which is essentially the same in all the traditions. According to Smith, faith thus 


\section{Maniraj Sukdaven}

understood comes to expression in what he calls the cumulative traditions that grow from it, using whatever expressions and practices the cultures concerned, provide.

For example, in their contact with Jesus, his earliest followers had the life-changing experiences of transcendence which Smith calls faith. From these experiences, shaped by their cultural setting, there developed a growing, cumulative tradition of worship, doctrine, creed, institution and scripture. Prozesky understood that if faith is the heart of religion, then it judges and transforms the cumulative tradition and not the other way around (Prozesky: 1999b:103).

Process Scholars. In 1978 Prozesky reviewed an introduction to process theology for the Journal of Theology for Southern Africa (Cobb \& Griffin 1977; Prozesky 1979). That was his first serious encounter with the process philosophy of Alfred North Whitehead and with the theology that has sprung from it. Interacting with the leading process theologians John B. Cobb Jr. and David Griffin during his sabbatical at Claremont, California in 1982, deepened and extended Prozesky's knowledge of and appreciation for process thought, but he had at that time yet to make a thorough study of it, especially in connection with ethics. The change came after the appearance of Prozesky's book Religion and Ultimate Well-Being: An Explanatory Theory in 1984, when the best responses to it came from process thinkers, chiefly Cobb and Schubert M. Ogden. Intrigued by this reaction, Prozesky made a much more thorough study of key process texts, focusing on ethics, from which two journal articles and two chapters in books emerged (Prozesky 1995; 1999a; 2000; 2009). It was quickly evident that the central role Prozesky discerned for human creativity in the rise and development of religion would go down well with process thinkers in view of the centrality of creativity in Whitehead's philosophy.

Feminist Scholars. The radical critique of androcentricity and patriarchy in Christianity by Mary Daly helped Prozesky to see the importance of the feminist perspective on patriarchal religion and society that was emerging in the 1970s (Daly 1973). Contact with both Ursula King and Rosemary Radford Ruether and their work took this process further, especially when they were visiting professors at the former University of Natal. What it did was alert Prozesky to the need for a much deeper critical awareness of the way patriarchy 
has affected, indeed infected, religion to the detriment of women and indeed also men. Thus it contributed in an important way to his critical theology and his still developing work on what he informally calls good and bad religion (cf. King 1998).

\section{Spiritual Leaders}

Together with the Anglican clergy who influenced Prozesky during his boyhood in Oudtshoorn and several others whom he encountered later like the late Catholic Archbishop of Durban, Denis Hurley, he mentions four spiritual leaders who have enriched his life and work. They are Desmond Tutu, Mahatma Gandhi, Jonathan Sacks and the Dalai Lama.

Desmond Tutu. Prozesky's recalls his first encounter with Archbishop Emeritus Desmond Tutu was in 1969 during his year as a temporary lecturer at Rhodes University. Tutu had returned from his studies at King's College, London and was lecturing at the former Federal Theological Seminary, then located in the small town of Alice, not far from Rhodes University. Upon hearing that Desmond Tutu would be delivering an open lecturer at the seminary, a group from Rhodes travelled there to hear him. Prozesky was one of them and vividly recalls the lecture. It was about Rudolf Otto's famous view that spiritual experience is centered on what Otto called 'the Holy' (Otto 1923). For Prozesky it was clear that a highly significant new voice had entered South African church life. He was at that time unaware that Otto had drawn some of his inspiration from the work of Friedrich Schleiermacher.

It was several years later, when Prozesky was a lecturer in the Department of Theology at the former University of Rhodesia, that his friendship with Desmond Tutu began. Tutu was then working for the Theological Education Fund in London, which assisted departments like the one in Harare, as it is now called. Prozesky acted as his host, showing him around and explaining the work of the department. Their links resumed when Tutu returned to South Africa and continue to the present. Reflecting on the Archbishop's impact on him, Prozesky singles out his powerful, prophetic ethical example, his deep personal spirituality and his inclusive view of the religions, not to speak of his unfailing generosity of spirit and action. For example, amidst his very heavy load of engagements and work he has twice readily agreed to provide endorsements for Prozesky's books. 
Gandhi. In Gandhi's project of a non-violent, ethical politics of liberation and in his pioneering openness to religions other than his own native Hinduism, Prozesky found both an ethical and spiritual inspiration. This led in 1993, the centenary of Gandhi's arrival in South Africa, to a prominent role in arranging a commemorative conference about the Mahatma at the University of Natal in Pietermaritzburg. From its papers emerged the book he helped Judith Brown edit called Gandhi in South Africa: Principles and Politics (Brown \& Prozesky 1996).

When confronted with the question of what Ghandi meant to him, Prozesky identifies Gandhi's encouragement to everyone who thinks, sometimes despairingly, that the task of making the world a better place is just too big. Prozesky suggests that if we ever feel that way we must remember that Gandhi's successful project of a spiritually-enriched, non-violent ethical politics, that liberated India from British domination, had a very small and lonely beginning. Here Prozesky has in mind the young Gandhi's moment of truth on Pietermaritzburg railway station in May 1893 when, having been thrown off the train from Durban because he was a dark-skinned man in an allwhite, first class part of the train, he had the inspiration for the idea that there must be a non-violent way to overcome violence. But the crucial step was that Gandhi did not just keep the idea to himself. He shared it and that is the essence of ethical power. It was a very small beginning which grew into a non-violent liberation movement that defeated a powerful, armed opponent. Prozesky sees this as a living demonstration that small acts of shared goodness's can at times become world-changing.

Jonathan Sacks. While occupying the position of Chief Rabbi of Britain's Orthodox Jewish congregations, Jonathan Sacks, now Lord Sacks, produced writings of great ethical and spiritual power, especially about what he calls 'the dignity of difference' - about how to affirm diversity in the world of religion (Sacks 2002). Prozesky met Sacks only once while he was in England and asked to meet the Chief Rabbi. Sack's response, given a very full diary, was to invite Prozesky to his home in the evening for a conversation. Prozesky describes his experience with Sacks as follows:

He actually invited me to his home in London, a total stranger, and I had an hour with him in his study. It was deeply inspiring to experience at first hand this man's wisdom and spiritual depth. I remember 
thinking as I left there that I have just been in the presence of a truly godly man.

This encounter and Sacks' books were a powerful support for Prozesky's conviction that beliefs and doctrines divide whereas ethical values are very much the same and can unite, at least at a practical level.

The Dalai Lama. In connection with the Dalai Lama, Prozesky mentions that he had studied Buddhism for his lectures in comparative religion in some detail and also spent time at the Buddhist Retreat Centre near Ixopo in his home province. He values his contacts with Buddhists there and elsewhere and especially values the Buddhist meditation practice. Interestingly, Buddhism was the first non-theistic religion that Prozesky encountered in the person of a Buddhist fellow student at Rhodes University when he was a first year student.

These earlier experiences came to a climax when the Dalai Lama was in South Africa. There was a meeting with him in Durban to which Prozesky was invited. He had known about the Dalai Lama's famous sense of humour, his wisdom and his views on ethics. Given the non-theistic nature of Buddhism, the question Prozesky put at that meeting was about what the Dalai Lama felt about those in a strongly theistic culture like South Africa who think atheism is a bad thing. Prozesky recalls the response from the Dalai Lama in the words something like: 'It really shouldn't be a problem, after all we Buddhists are atheist'. Thus Prozesky remarks,

Here was an openly atheistic, deeply spiritual and saintly man with great ethical depth. It was moving to experience something of his spiritual vibrancy in person.

\section{Religious Pluralism and Critical Theology}

The growing experience of contact with people from other faiths and philosophies that began in Prozesky's boyhood and has continued ever since has already been introduced. It is no surprise, then, that the ethical and theological implications of religious pluralism became a central scholarly and personal concern for him, forcing him to ask searchingly critical questions about traditional, orthodox Christian beliefs. Asked about this, he explains that the existence of other faiths and philosophies of great moral and intellectual 


\section{Maniraj Sukdaven}

quality and followed by two-thirds of the world's people posed for him, insuperable problems with core, traditional Christian doctrines like exclusive revelation and especially salvation through belief in Christ and in no other way. So he came to reject, as unfair and logically incompatible with the nature of a perfect God, the idea that a single belief-system has a monopoly on truth, goodness and spiritual validity.

Two key realities emerged from Prozesky's personal encounters with and comparative studies of other religious traditions and of secularistic philosophies which are discussed below. Firstly, the various faiths and philosophies show remarkable convergence about core ethical values, but are divided by doctrinal teachings and creeds. He maintains that,

We believe some incompatible things. God is either a Trinity or not, reincarnation either happens or doesn't. And if you emphasize the doctrines you end up with division and at times alienation and conflict, and we have had lots of that. But if you emphasize moral quality you find that kindness, justice and truthfulness are present in people of any known belief-system, religious as well as secular.

Asked if these findings involving religious pluralism caused him to question his own Christian beliefs, he is unequivocal in saying that they did, adding that his work in the philosophy of religion in the 1970s and 1980s raised its own critical questions about Christian beliefs. What did not change was his commitment to Christianity's ethic of love and justice and his profound admiration for Christ, noting that this ethic was part of Christianity's inheritance from Judaism.

The first published expression of Prozesky's critical theology marked the end of his ability to accept Barth's theology. It was a paper titled, 'The Divine Absentee: Karl Barth and the "Death-of-God" Theologians' (Prozesky 1981c). In the philosophy of religion at the time central concern was with religious language. This led to Prozesky's work on cultural relativity in religion, which he applied to Christology in a paper in 1981 (Prozesky 1981d). In it he argued, among other things, that all religious beliefs are culturally relative. This was another facet of his growing rejection of absolutism about theological matters.

While Prozesky's concern with what he sees as logical problems in Christian doctrine was and remains a key problem for him, it was the ethical 
criterion that increasingly dominated his critical theology from 1985 onwards. The ethical question that concerned him most was this:

What is it about a religion that claims to be uniquely the gift of a perfect God who was embodied exclusively in a perfect Saviour and is guided by a unique, divinely inspired scripture that none the less enabled it to give succor to apartheid and before that, to slavery and other terrible evils?

His answer is that whatever its source, such a religion as manifested in its teachings and practices and indeed also in its scriptures, must be just as fallible and flawed as anything else we human create, and is therefore permanently open to creative change for the better by its adherents.

This and other critical conclusions found expression in a set of essays and published conference papers in the mid-1980s, and afterwards, that together expressed Prozesky's critical theological writings, a concern to which he says he has returned to in his current work (Prozesky 1985a; 1985b; 1986a; $1988 b ; 1990 ; 1991 ; 1992)$. The same commitment to ethical and logical critical evaluation of core Christian beliefs led to his main work of this kind, his evaluation of Christian theism, discussed below.

Asked to elaborate on what led to this strongly ethical criticality, Prozesky's response was as follows:

What stood out for me even in my teens was what we would now call the ethical dimension of life: the idea that it is important to oppose injustice, it is important to live honourably, truthfully and lovingly, and so on. And then you see that across the road there is a church which is preaching that apartheid is God's will, and even in your own your hear that Jews and others who do not accept Christ as Saviour are all going to hell, things that were and remain morally unacceptable to me.

Prozesky continues to elaborate by saying that,

So while I was never greatly drawn by worship or creed or even scripture, I was and remain powerfully drawn by the practice of love and the project begun by Jesus of Nazareth. Thus began a gradual movement away from institutional religion. I never formally left the 
church but I have certainly ceased active membership, partly because I would hear very little doctrinal there that I could really believe in or be passionate about, though I love traditional church music and architecture. I moved also because I got tired of hearing one strand of the great spiritual story of the earth, which I heard over and over and over again, but never some of the beautiful teachings in the Qur'an, the Bhagavadgita or the Dharmapada., let alone the Humanist Manifesto, all of which I was discovering in my academic life as containing many wonderful resources. It became clear to me that the university and the library were better places for real truth-seeking than any church known to me, though that never diminished my admiration and gratitude for the love I experienced in the church.

\section{The God Question}

Shortly before becoming a Dean of Humanities in 1991, Prozesky completed a book called A New Guide to the Debate about God (Prozesky 1992a). In it he set out and evaluated the case both for and against the belief that the Deity of traditional Christianity exists. He concluded that this was unlikely on logical, empirical and ethical grounds, but maintained that an alternative theism could be developed that would have at least adequate justification. Prozesky adds that his 1992 book was intended to be the predecessor to a second book in which he would set out that alternative approach to theism, but has so far not been able to write that book.

Asked, some twenty years later, whether God exists for him, Prozesky's reply reveals some of the results of his work on and experience of the different religions, both theistic and non-theistic, of his earlier critiques of traditional Christian theism (Prozesky 1985a; 1985b) and of his work in developing the critical theology reviewed above.

He starts his reply by saying that it depends on what one means by the term 'god'. For Prozesky, god as 'An all-powerful, authoritarian sovereign up in the heavens does not exist'. According to Prozesky what certainly is absolutely real is 'a great, wonderful, transforming power that far surpasses our own powers, which is real and available right now'. And that to him is what really matters. He then uses a distinction made by the $19^{\text {th }}$ century German philosophy Gottlob Frege who taught the distinction between the sense and the reference of nouns. The sense refers to the meaning of a word. The reference 
means that to which it points. As an example he mentions the word dragon. Here the word means a horrific, fire-breathing beast. What it refers to is a fictitious creature in literature or perhaps, metaphorically, a very nasty human being.

He continues that the word god means various things. He mentions that, 'etymologically the roots are interesting to look at'. The word Deity for example links up with Deva in Sanskrit having to do with brightness and light. The English word God evidently derives from a Germanic word signifying awesome power and so on. According to Prozesky. 'Paul Tillich, half a century ago, taught us to understand the meaning of the word as the reality which ultimately concerns us' (Tillich 1951-63). He adds that,

I like this because it is true of everybody. We are all affected by whatever is the ultimate reality. When, next, you ask what the word God refers to, and you know that most people in our parts of the world say it refers to a Supreme Being, you must, if you respect all the evidence, accept the fact that the so-called eastern religions like Buddhism are non-theistic. They hold that the word god refers to a fiction, a mere belief that has no objectively existing referent, and such people are no less intelligent, educated, ethical and spiritual deep than our theists.

Therefore according to Prozesky, his understanding of the word god refers to the ultimate reality which is experienced as a supremely transforming but mysterious power. He suggests the use of poetry, metaphor and music in expressing what the word refers to, namely this 'wonderful, transcendent but available transforming power that uplifts and inspires us and brings us what religious people called blessings in all sorts of ways'.

Prozesky adds that he thinks one has to reject dogmatism and exclusivism about the way one speaks of the ultimate reality. In his own words, 'We name it as humans, and we humans are not gods and all too often we make a God out of our fallible human god- talk'. Earlier in his career he read some wonderful advice by the then leading British philosopher of religion, Ian Ramsey. Ramsey, in his book 'Religious language: An empirical placing of theological phrases' (1963), made the point that the idea of god is not like an excellent photograph of the Deity that is delivered to us the way diplomats send precise messages to their governments in the diplomatic bag. God-talk, he said, 


\section{Maniraj Sukdaven}

is 'significant stuttering'. How can you be caught up into the mysterious reality of something magnificently good, perfect and beautiful and not be speechless? To this Prozesky adds, 'we go into our religious institutions and make gods out of the words we use to refer, always haltingly, to the ultimate reality'.

Therefore Prozesky concludes that the question really is whether there is an ultimate reality that is the greatest, richest reality we could ever encounter, one that draws us by its power and its availability. His response is that,

there certainly is such a reality. It is finitely and fallibly called God in some culture but not in others, with equal justification. In support of his view he adds that classical Christian theology has always spoken of God as ineffable, as that which is beyond word, too rich for words.

\section{Secular Humanism and Marxism}

Prozesky denied the perception by some that he became a secular humanist. He explained that it was only an academic pursuit and never endorsed secular humanism personally. He pursued an academic research of secular humanism when the Department of Religious Studies at in the former University of Natal in Pietermaritzburg defined its task as the study of belief systems, secular as well as religious. The reason for that approach was the conviction that one cannot have an adequate understanding of the religious world if one has no understanding of those who criticize and reject it. So as well as studying and teaching students about the various religions, they specifically included Marxism and secular humanism.

Prozesky had previously done research on Marxism when he was teaching at the University of Rhodesia, a country that did not have South Africa's erstwhile prohibition of access to Marxist literature. But he had not grappled with secular humanism until returning to South Africa in 1977. That was the extent of secular humanism for him, except for taking on board some of the secularist criticism of religion that he found convincing. As to why he had not embraced secular humanism as a personal philosophy, he explains that he rejects the wholesale dismissal of all religion by secular humanism, and by Marxism, which are very anti-religious. He does not object to the rejection of what he calls bad religion but to the dismissal of the many things in the world's religions that are great and good, ethically, philosophically and spiritually. He adds that he finds a label reportedly proposed by Ninian Smart much more 
accurate, namely transcendental humanism, provided transcendence is not understood dualistically.

'Equally', says Prozesky, 'you quickly discover that the ethical values espoused by secular humanists, by example in work of Paul Kurtz, are essentially the same as those of the religions' (Kurtz 1988).

So, you conclude that in the quest for a more humane world, a more environmentally safe world, what we call ethics evidently touches something in us that is more universal and deeper than the cumulative traditions of religion, as Wilfred Cantwell Smith called them.

Similarly, he maintains that you cannot study Marx without being moved and impressed by his sense of outrage at the exploitation of the poor, by the raw capitalism of the $19^{\text {th }}$ century. What stands out is someone with a rage against such injustice and exploitation, which reminds Prozesky of the great Hebrew prophetic denunciation of injustice we find in the Hebrew scriptures. The world-views of Marx and the Hebrew prophets could not be more different but their moral passion against injustice and oppression is identical.

\section{Explaining Religion}

Probing the nature of religion has been a long-standing concern for Prozesky. What is his understanding of this phenomenon? He identifies five characteristics. Retaining the view of his first book (Prozesky 1984), he sees religion firstly as the human quest for ultimate well-being. Secondly, what answers this quest is the experience of a surpassing, uplifting but always mysterious power, experienced as that which makes us the happiest, most fulfilled, and morally best, which by its nature evokes commitment. Thirdly, religion in its cumulative traditional forms is an artifact; it is a human creation embedded in our various cultures in response to the experience of contact with that transforming power which some but not all traditions believe is a personal, Supreme Being. In the fourth place, while the ways in which humans think of and express that power are fallible and can be very imperfect, the mysterious power itself is no mere delusion as Sigmund Freud and others have maintained. Fifthly, religion is seen as the transforming enrichment of what Prozesky 


\section{Maniraj Sukdaven}

would call true religion, which is available right now and not something postponed to an afterlife.

Looking back at his first book in 1984, Prozesky adds two comments. Firstly, it showed him that within the experiential approach to religion, what is fundamental is our valorizing, context-embedded human nature. How and why we come to value what we value most is the essential question to ask and answer. Secondly, he remains convinced of the essential correctness of his naturalistic explanation of why religion exists, deriving it from causes in our human nature and in the way the surrounding world affects us. While these are purely natural causes, they do not of themselves mean that there is no other reality than the natural universe, for the question can always be asked whether the natural universe points beyond itself to an anterior source (Prozesky 1986b; 1988).

\section{From Theology and Religious Studies to Ethics and Spirituality}

In his academic work Martin Prozesky began as a lecturer in systematic theology in 1969, moved into religious studies, teaching comparative religion and the philosophy of religion, and from 1997 he has concentrated on comparative, applied ethics and on inclusive spirituality. The opportunity to move into ethics arose from his time as Dean of Humanities from 1991 to 1995, which coincided with the end of apartheid in 1994. Prozesky raised with others the question of the future of the humanities in a post-apartheid society and came to the conclusion that there was an acute need for a new approach to the gravely damaged state of morality in the country.

Given South Africa's multi-cultural character, Prozesky believed that it was time for a fresh approach to ethics both as an academic discipline and as ethical practice or morality because for him morality was largely defined by Christianity and by western philosophy. He therefore questioned whether that would suffice in a new, inclusive democracy with a diversity of faiths and philosophies and a large African majority. He strongly disagreed with the notion that, with important new insights into morality coming from the social and natural sciences, that one can still look to just western philosophy and theology for ethical wisdom. He did not think so, and therefore when his term as Dean was over, he proposed to Professor Brenda Gourley, the ViceChancellor at the time, that the university should set up a multi-cultural, multi- 
disciplinary ethics centre with special attention to African ethics to drive this project, which Prozesky was willing to develop. She gave it her support and helped find generous external funding from the Unilever Foundation for Education and Development. Thus, Prozesky became the founding director of the Unilever Ethics Centre on the Pietermaritzburg campus, until he opted for early retirement in 2007 to concentrate on ethics training in the wider community and on thinking out a way of bringing together the main strands in his life and thought in connection with spirituality. This is evident in the chapters published on 'ethical spirituality' (Prozesky 2001) and on 'ethics, spirituality and the secular' (Prozesky 2006).

\section{Exploring the Ethical Dimension of our Existence and the Global Ethics Project}

Prozesky does not think that humans are intrinsically good. Human evil is too real for him to accept that human beings are intrinsically good, but they are also not intrinsically bad. He holds that human beings are morally ambivalent and adds that, 'any traditional understanding of the idea of original sin clashes with the evidence'. 'One of the good things about secular humanism', says Prozesky 'is its argument that there is a far too negative interpretation of humanity in traditional Christianity'.

When asked who or what determines good and evil, Prozesky response is that, 'in practice, we humans do, but we don't do it arbitrarily'. He asks,

Why is there such widespread agreement about core values in every culture I have studied? It can't be cultural, because the cultures are so different. Could it something in human nature? That is partly why I became interested in the biology of ethics which is showing that we are made in such a way, biologically, that unless certain values are prioritized and practised we cannot thrive and will not even survive. For example, working together, co-operatively and helpfully, with others, is a condition of survival and yields the moral virtue of unselfishness. We humans cannot achieve the well-being we all want on our own so we have to learn how to work together, and that requires respect for others, truthfulness, supportiveness and mutual help, which are central to what we discern as right and good. Well-being requires teams rather than standout, self-concerned individuals, and so on. 
For Prozesky there is very good scientific evidences that 'there is a source for morality in our biological make-up, but only up to a point, for we also have to choose whether to live selfishly or caringly, and so on'. That of course opens the door to a great deal of wicked choosing as well as to noble choosing, but for him it is 'our choices, together with our underlying biology that ground morality'. He believes that the idea that somebody out there tells us what is right and wrong and commands us to behave in certain ways merely creates moral dependency in us.

Not surprisingly, Prozesky has turned to human brain science for further insight into bioethics. He began to do some serious reading about it and consulted colleagues in neurobiology at his university's medical faculty. As a result he was able to include this new information in his account of ethics in his book called Conscience: Ethical Intelligence for Global Well-Being (Prozesky 2007). He now uses it in all his ethics training, along with information about the various value-systems of society, not least African ones, treated with equal respect and openness. He believes that exclusivism about ethics is just as unacceptable as in religion.

\section{Present and Future Research Projects}

As to the present and future projects, Prozesky identifies two themes. The first one is his work on global ethics, which is an ongoing project that was also part of his 2007 book. For a global ethic that is fully ethical, his use of brain science and comparative ethics is highly relevant. Using them as sources for ethical principles and practice is, according to him, "completely fair and inclusive because we all have exactly the same brain architecture, which has nothing to do with cultural differences. The biology of ethics therefore gives us an empirically verified and shared source'. As he says,

We don't have to learn Sanskrit or Hebrew or Arabic or Greek or Latin or Zulu to do this, or believe this or that doctrine; we just have to learn from our own experience, and our experience is made possible by certain features of the brain, along with the cultures our powerful brains and some other features of our biology like opposable thumbs enable us to create and modify. A global ethics project cannot be truly global or truly ethical if it rests on sources that are not universally 
available, or excludes important parts of the great range of valuesystems in the world.

That, for Prozesky, is the problem with Hans Küng's otherwise admirable, pioneering work on global ethics (Küng 1997).

There is thus the real possibility now of a shared, co-operatively constructed global ethic. Related to this interest is another of Prozesky's current research interests, which is the Progressive Christianity movement, which understands itself and its loyalty to Jesus of Nazareth in strongly ethical terms (Brown 2008). While he has reservations about some of the connotations of the term 'progressive', he is drawn to the powerful ethical emphasis of the movement, for, as he explains, he 'is not primarily interested in doctrinal issues'. He fears that 'they are side-tracking us from the urgent business of addressing the great global problems of poverty, violence, gender injustice and the environment'. What also appeals to him about Progressive Christianity is that,

it tries to create a congenial space for people who are no longer at home in their churches, but who do not want to drift off into secularism. These are people at or just beyond the outer edges of church life but who are still drawn to the ethics they trace back to Christ and to the friendship of others who share that interest.

Having asked what this new movement can offer to the project of creating a global ethic and a global spirituality, Prozesky believes that,

It is very open-minded and science-friendly, fully open to the best of modern knowledge and to other spiritual traditions and could thus be on the path to what the world needs most, and that is a global conscience which is both spiritually rich and open to secular insights.

The topic of what Prozesky calls ethico-spirituality is also part of his present and future work. Troubled by the way religions so often and so deeply divide and even alienate people from one another, he ponders the question of whether there might be a way, through global ethics, to a new and inclusive spirituality that takes both the secular world and our religious heritage very seriously (Prozesky 2006). In this connection he notes approvingly the 


\section{Maniraj Sukdaven}

important recent work of Lloyd Geering (Geering 2013). Among other contentions, the Geering writes that we are now being called upon to embark on a project of earth salvation because we are now endangering our planet and the whole human future (Geering 1999). Prozesky adds that for this to happen

we also need a new project to save religion itself, to rescue what is truest and best in it from what is harmful, divisive and in conflict with the evidence now available to us about the religious and ethical dimensions of human existence.

\section{Conclusion}

This interaction with Martin Prozesky and the numerous valuable insights provided by him in the interview, his interactions with well known experts in the fields of religion and ethics and his numerous academic publications is an indication of a great scholar who is a deep thinker, yet practical and humble in many respects. His contribution towards the ethical well-being of society, as indicated in this article, is filled with a great concern for humanity. His scholarly works bears testimony to an unselfish human being steeped in the quest for a global ethical well-being. It was indeed a tremendous experience to listen to and understand his views on different aspects of issues pertaining to the well-being of humanity.

\section{References}

Brown, D. 2008. What Does a Progressive Christian Believe? A Guide for the Searching, the Open and the Curious. New York: Seabury Books.

Brown, J.M. \& M. Prozesky (eds.) 1996. Gandhi in South Africa: Principles and Politics. Pietermaritzburg \& New York: University of Natal Press, \& St. Martin's Press.

Cobb, J.B. Jr. \& D.R. Griffin 1977. Process Theology: An Introductory Exposition. Belfast: Christian Journals Limited.

Daly, M. 1973. Beyond God the Father: Towards a Philosophy of Women's Liberation. Boston: Beacon Press.

de Gruchy, J.W. 2006. Being Human: Confessions of a Christian Humanist. London: SCM Press. 
Geering, L. 1980. Faith's New Age: A Perspective on Contemporary Religious Change. London, Collins.

Geering, L. 1991. Creating the New Ethic. Wellington: St Andrew's Trust. Geering, L. 1994. Tomorrow's God: How We Create Our Worlds. Wellington: Bridget Williams Books Limited.

Geering, L. 1999. The World to Come: From Christian Past to Global Future. Wellington: Bridget Williams Books Limited.

Geering, L. 2009. Coming Back to Earth: From gods, to God, to Gaia. Salem, Oregon: Polebridge Press.

Geering, L. 2013. From the Big Bang to God. Wellington: Steele Roberts Publishers.

Hardy, A. 1979. The Spiritual Nature of Man: A Study in Contemporary Religious Experience. Oxford: The Clarendon Press.

Hick, J. 1989. An Interpretation of Religion: Human Responses to the Transcendent. London: Macmillan.

Huddleston, T. 1956. Naught for your Comfort. New York: Doubleday \& Company.

King, U. 1998. Faith and Praxis in a Postmodern Age. London: Cassell.

Küng, H. 1997. A Global Ethics for a Global Politics. London: SCM Press.

Kurtz, P. 1988. The Ethics of Humanism. Buffalo: Prometheus Books.

Luthuli, A. 1962. Let My People Go: An Autobiography. Johannesburg \& London: Collins.

Moore, B.S. 1973. The Challenge of Black Theology in South Africa. London: C. Hurst.

Otto, R. 1923. The Idea of the Holy. Oxford: Oxford University Press.

Prozesky, M. 1976. A Critical Examination of the Pietistic Element in the Religious Philosophy of Friedrich Schleiermacher. Unpublished D.Phil. dissertation. University of Rhodesia, Salisbury.

Prozesky, M. 1979. Review of Process Theology: An Introductory Exposition, by John B. Cobb Jr. and David Ray Griffin. Journal of Theology for Southern Africa 26,March:76.

Prozesky, M. 1981a. Friedrich Schleiermacher's Earliest Account of Religious Experience. Religion in Southern Africa 1,2,July: 71-86. Available at: https://www.jstor.org/stable/pdf/24763718.pdf

Prozesky, M. 1981b. The Young Schleiermacher: Advocating Religion to an Age of Critical Reason. Journal of Theology for Southern Africa 37: 50ff. Prozesky, M. 1981c. The Divine Absentee: Karl Barth and the 'Death of God' 
Theologians. Theoria 57, October:39ff.

Prozesky, M. 1981d. Christology and Cultural Relativity. Journal of Theology for Southern Africa 35,June: 44ff.

Prozesky, M. 1984. Religion and Ultimate Well-Being: An Explanatory Theory. London: Macmillan and New York: St Martin's Press.

Prozesky, M. 1985a. A Critique of Theistic Religion. South African Journal of Philosophy 4:55ff.

Prozesky, M. 1985b. Judging Religion. In Sontag, F. \& J. Roth (eds.): The Defense of God. New York: Paragon House.

Prozesky, M. 1986a. Can Christians Overcome Apartheid? Journal of Theology for Southern Africa 54,March: 53ff.

Prozesky, M. 1986b. Philosophical Cosmology and Anthropology in the Explanation of Religion. Theoria 66,May: 29ff.

Prozesky, M. 1988a. Explanations of Religion as Part of and Problem for Religious Studies. Religious Studies 24,:303ff.

Prozesky, M. 1988b. Why did God Hold Back at Auschwitz? Review article of Albert Nolan. God in South Africa: The Challenge of the Gospel. Cape Town: David Philip. Southern African Review of Books FebruaryMarch:14f.

Prozesky, M. 1990. Christianity Amidst Apartheid: Selected Perspectives on the Church in South Africa. London: Macmillan. South African edition 1990. The Church in South Africa. Johannesburg; Southern Book Publishers.

Prozesky, M. 1991. The Challenge of Other Religions for Christianity in South Africa. Journal of Theology for Southern Africa 74:35-45.

Prozesky, M. 1992a. New Guide to the Debate about God. London: SCM Press and Pietermaritzburg: University of Natal Press.

Prozesky, M. 1992b. Towards a Criteriology of Religions. Journal for the Study of Religion 5,1,May:67-77. Available at:

https://www.jstor.org/stable/pdf/24764138.pdf

Prozesky, M. 1995. The Philosophical Anthropology of A.N. Whitehead. South African Journal of Philosophy 14,2,May:54-59.

Prozesky, M. 1995. Experientialist and Evidentialist Approaches to the Justification of Theism. Journal for the Study of Religion 8,2,September: 47-58. Available at:

https://www.jstor.org/stable/pdf/24764008.pdf

Prozesky, M. 1999a. Ethics in Process Perspective. South African Journal of 
Philosophy 18,1: 1-17.

Prozesky, M. 1999. Religion and the 1996 South African Constitution.

Scriptura 69: 103-110. Available at:

http://www.scielo.org.za/scielo.php?script=sci issuetoc\&pid=1011-

760120140001\&lng=en\&nrm=iso

Prozesky, M. 2000. The Process Worldview as an Ethic in a World of Uneasy

Pluralism, Incomplete Democratisation and Economic Injustice. In

Cochrane, J.R. \& B. Klein (eds.): Sameness and Difference: Problems and

Potentials for Civil Society in South Africa. Washington DC: Center for

Philosophy and Values.

Prozesky, M. 2001. 'Everything that rises must converge': Some Ideas for an

Ethical Spirituality and for a Spiritually-enriched Ethic. In King, U. (ed.):

Spirituality and Society in the New Millennium. Brighton: Sussex

Academic Press.

Prozesky, M. 2006. Ethics, Spirituality and the Secular. In du Toit, C.W. \&

C.P. Mayson (eds.): Secular Spirituality as a Contextual Critique of Religion. Pretoria: UNISA.

Prozesky, M. 2007. Conscience: Ethical Intelligence for Global Well-Being.

Pietermaritzburg: University of KwaZulu-Natal Press.

Prozesky, M. 2009. Chapter 1: Cinderella, Survivor and Saviour: African

Ethics and the Quest for a Global Ethic. In Murove, M.F. (ed.): African

Ethics: An Anthology of Comparative and Applied Ethics. Pietermaritzburg: UKZN Press.

Prozesky, M. 2009. Chapter 16: Well-Fed Animals and Starving Babies:

Environmental and Developmental Challenges from Process and African

Perspectives. In Murove, M.F. (ed.): African Ethics: An Anthology of

Comparative and Applied Ethics. Pietermaritzburg: UKZN Press.

Prozesky, M. 2011. What Ethics can learn from Religion Studies. Unpublished paper delivered at the annual conference of the Association for the Study of Religion in Southern Africa, University of KwaZulu-Natal, Durban.

Prozesky, M. 2012. John Hick's Interpretation of Religion: A Perspective from

South Africa. Journal for the Study of Religion 25,1: 5-13. Available at:

https://www.jstor.org/stable/pdf/24798117.pdf

Ramsey, I.T. 1963. Religious Language: An Empirical Placing of Theological Phrases. London: Macmillan.

Sacks, J. 2002. The Dignity of Difference: How to Avoid the Clash of Civilizations. London: Continuum. 


\section{Maniraj Sukdaven}

Smart, N. 1969. The Religious Experience of Mankind. London: Collins.

Smart, N. 1979. Faith and Belief. Princeton: Princeton University Press.

Smart, N. 1997. Dimensions of the Sacred: An Anthology of the World's Religions. London: Fontana.

Smith, W.C. 1978. The Meaning and End of Religion. London, SPCK.

Tillich, P. 1951-1963. Systematic Theology. Volumes I - III. Chicago: UCP.

Wainwright, W.J. 1984. Wilfred Cantwell Smith and Belief. Religious Studies 20,3,September: 353-366.

Maniraj Sukdaven Department of Religion Studies

University of Pretoria sukdavenm@gmail.com 